ISSN 2413-0877 Volume 2 (2015) 549-551

The 3rd International Conference on Biological Science 2013

(The 3rd ICBS-2013)

\title{
NEW REPORT ON THE DIET OF THE BLUE WHISTLING-THRUSH (Myophoneus caeruleus) IN KAKEK BODO WATERFALL, STATE-OWNED FOREST IN PRIGEN, PASURUAN (EAST JAVA)
}

\author{
Heru Cahyono and Haris Eka Pramudhita \\ Malang Eyes Lapwing (MEL) Bird Study Group, Biology Department, \\ Faculty of Mathematics and Science, State University of Malang, Jl. Semarang 5, Malang, Indonesia 65145. \\ Heru Cahyono: hc_garuda@yahoo.com
}

\begin{abstract}
The Blue Whistling-Thrush (Myophoneus caeruleus) is a member of Turdidae family which is comprised of six races distributed from Turkestan up to India and China, Southeast Asia, Malay Peninsula, Sumatera, and Java. This bird can be found around large rivers or between ridges in the forests. On 13 December 2012, we conducted an observation around the Kakek Bodo Waterfall's camping ground and tourism site, Prigen, Pasuruan. The observation resulted in the sightings of five endemic bird species (the Olive-backed Tailorbird, Crescent-chested Babbler, Yellow-throated Hanging-parrot, Javan Banded-pitta, Lesser Forktail), and a bird with minimal record bird in Java, the Thick-billed Flowerpecker. Another result of the observation is a new data on the diet of the Blue Whistling-thrush. This species is known to prey on snails, beetles, maggots, worms, and water bugs; however, that one bird we observed was preying on a snake (from the genus Dendrelaphis). This species had also been reported to scavenge for leftovers thrown away by food vendors in the tourism site, so that its behavior has gradually changed.
\end{abstract}

Key words: Blue Whistling-thrush, Dendrelaphis snake, diet, Kakek Bodo waterfall.

\section{INTRODUCTION}

The Blue Whistling-Thrush (Myophoneus caeruleus) is a member of Turdidae family which is comprised of six races distributed from Turkestan up to India and China, Southeast Asia, Malay Peninsula, Sumatera, and Java. The subspecies found in Java is flavirostris Horsfield, 1821. Its distribution is limited only in lowland forests and medium-elevation hills (MacKinnon et al., 2000) up to 1650 meters above sea level like in Cangar (Foto Biodiversitas Indonesia, 2012). This paper will discuss the report on the sighting of Blue Whistling-thrush in the state-owned forest, Prigen, Pasuruan where an individual was spotted while preying on a Dendrelaphis snake.

\section{MATERIALS AND METHODS}

Observation was conducted on 13 December 2012, around the camping ground and tourism site of kakek Bodo waterfall, Prigen, Pasuruan. The area is under the management of Perhutani (state-owned forest) which is dominated by Pine and Swietenia macrophylla trees production. Only the area surrounding the waterfall is still covered by variation of plants and inhabited by several bird species. As a matter of fact, the condition has changed due to deforestation and minor natural disasters (blizzards, hard rains, etc.) for these past few years. Species identification follows the field-guide book of MacKinnon et al. (2000).

\section{RESULTS AND DISCUSSION}

During the observation in the production forest, we encountered these bird species:

ISSN 2413-0877 (C) 2015 The Authors.

Published by KnowledgeE Publishing Services This is an open access article under the CC BY-NC-ND license (http://creativecommons.org/licenses/by-nc-nd/4.0)

Selection and Peer-review under responsibility of the 3rd ICBS-2013

Doi http://dx.doi.org/10.18502/kls.v2i1.214 
Sooty-headed Bulbul (Pycnonotus aurigaster), Olive-backed Sunbird (Nectarinia jugularis), Yellow-vented bulbul (Pycnonotus goiavier), Small minivet (Pericrocotus cinnamomeus), Scarlet minivet (Pericrocotus flammeus), Olive-backed Tailorbird (Orthotomus sepium), Horsfield Babbler (Malacocinla sepiarium), Crescent-chested Babbler (Stachrys melanothorax), Javan Banded-pitta (Pitta guajana), Great Tit (Parus major), Velvent-fronted Nuthatch (Sitta frontalis), Chesnut-bellied Malkoha (Rhampococcyx curvirostris), Blackwinged Flycathershrike (Hemipus hirundinaceus), Fulvous-breasted Woodpecker (Dendrocopos macei), Grey-cheeked Green-pigeon (Treron griseicauda), Cave Swiflet (Collocalia linchi), Crested Serpent-eagle (Spilornis cheela), Yellow-throated Hangingparrot (Loriculus pusillus), Blue-eared Barbet (Megalaima australis), Rusty-breasted Cuckoo (Cacomantis sepulcralis), and Red Jungle-fowl (Gallus varius),

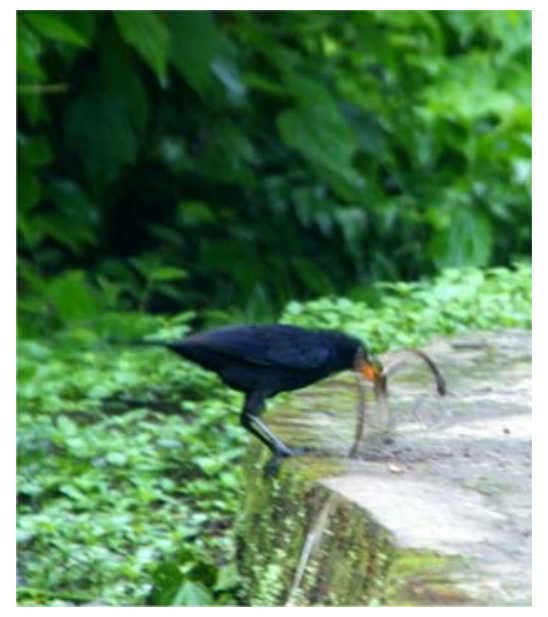

Figure 1. A Blue Whistling-thrush whipping down a snake before eating it. Prigen, 13 December 2012. Photo by Heru Cahyono

When we enter the area around the river heading to the waterfall, we found several species similar to what we found in the production forest such as the Lesser Shortwing (Brachypteryx leucophrys), Lesser Forktail (Enicurus velatus), White-crowned Forktail (Enicurus leschenaultii), Indigo Flycatcher (Eumyias indigo), and Blue-whistling Thrush (Myophoeus caeruleus).

The last mentioned species was an adult, who was struggling to prey on a snake. This information is gripping because the diet of this species is known to consist of snails, beetles, maggots, worms, and waterbugs (MacKinnon, 1990 \& 2000). On being observed, the bird was whipping down the snake upon a rock until it fainted, then flew away with the prey to eat it in a more proper place. The process of whipping down the snake was well-documented. After studying and discussing it with several fellow researchers, we concluded that the snake belongs to the genus Dendrelaphis. Dendrelaphis is a member of Colubridae family which is not poisonous, slim, large-eyed, and ventral and subcauda scales are formed by cartilages and are connected into a chain of hard bulges stretching throughout its body length. The males are generally smaller than the females, and tend to have more vibrant color (Mackay, 2006). The genus of Dendrelaphis consists of five species distributed in Java, one of which is endemic in Java (van Rooijen \& Vogel, 2008). 


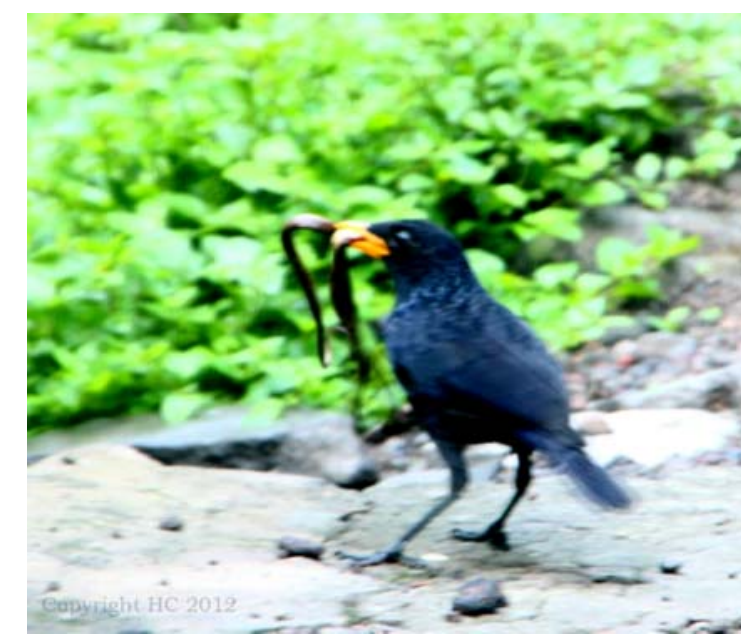

Figure 2. The Blue Whistling-thrush before flying away with the beaten-to-death snake. Photo by Heru Cahyono

The discussed Blue Whistling-thrush was found at 1100 meters above sea level by the outlet stream of Kakek Bodo waterfall ( $\left.7^{\circ} 41^{\prime} 59.10^{\prime \prime S} 112^{\circ} 37^{\prime} 29.00 " \mathrm{E}\right)$. The blue Whistlingthrushes in this place do not seem to be disturbed by the human activities. It is not unusual to see this bird frisking about the stones in the river, not far from the tourists. This Least Concern (BirdLife, 2001) species has also been reported to scavenge for leftovers of foods thrown away by vendors nearby, so that their natural behavior has been gradually altered.

\section{ACKNOWLEDGMENT}

We would like to thank Ms. Dwi Listyorini (Department of Biology, State University of Malang), Fajar Dwi Nur Aji (Pengendali Ekosistem Hutan-BBKSDAJATIM), Syahputra, Imam Taufiqurrahman (Kutilang Information for Bird Conservation), and our fellow birdwatchers at Malang Eyes Lapwing and SERIWANG (Serikat Birdwatcher Ngalam) who have contributed to the publication of this paper: Windri Hermadiyanti, Riri Wiyanti Retnaningtyas, and Swasti Prawidya Mukti.

\section{REFERENCES}

Mackinnon, J., K. Phillipps, and B. van Balen. 2000. Burung-burung di Sumatera, Jawa, Bali dan Kalimantan. Pustlitbang Biologi LIPI and Birdlife International Indonesia Programme, Jakarta.

Foto Biodiversitas Indonesia. 2012. Biodiversitas Indonesia (Bhinneka Flora Fauna Nusantara) www.fobi.web.id edisi Ekspedisi FOBI Vol. 02/No. 02/ 2012.

MacKinnon, J. 1990. Panduan Lapangan Pengenalan Burung-burung di Jawa dan Bali. Gajah Mada University Press, Yogyakarta

Mackay, J.L. 2006. Reptil dan amfhibi di Bali. Krieger. Malabar.

Birdlife international. 2001. Threatened Birds of Asia-the Birdlife International Red Data Book. Birdlife International, Cambridge.

Van Rooijen, J., and G. Vogel, 2008. A New Species of Dendrelaphis (Serpentes : colubridae) from Java, Indonesia. National University Singapore. 